\title{
A CLINICAL AND HISTOPATHOLOGICAL STUDY OF CUTANEOUS AMYLOIDOSIS
}

\author{
Anuja E. George1, Renjitha S. Rajan², Nandakumar G3 \\ 1 Professor and HOD, Department of Dermatology and Venereology, Government Medical College, Trivandrum. \\ ${ }^{2}$ Senior Resident, Department of Dermatology and Venereology, Government Medical College, Trivandrum. \\ ${ }^{3}$ Additional Professor, Department of Pathology, Government Medical College, Trivandrum.
}

\section{ABSTRACT}

\section{BACKGROUND}

Cutaneous amyloidosis refers to deposition of amyloid in the skin and can be primary or secondary. Systemic amyloidosis can also have skin involvement with amyloid deposits.

Aims- 1) To study the clinical presentation and the histopathological features of different types of cutaneous amyloidosis; 2) To study the association of cutaneous amyloidosis with other diseases; 3) To analyse the possible role of friction in inducing the condition.

\section{MATERIALS AND METHODS}

All such patients during a period of one year were subjected to a detailed history taking, clinical examination, blood and urine investigations and histopathological evaluation including special stain for amyloid. Only biopsy-proven, Congo red positive cases were included in the study.

Statistical Analysis: Method used was descriptive statistics.

Design and Setting- The study is a case series of patients with clinical and histopathological features of cutaneous amyloidosis attending the outpatient wing of Department of Dermatology and Venereology, in a tertiary care teaching hospital.

\section{RESULTS}

The clinical and histopathological features were studied and associations with other diseases were noted - 26.3\% had pre-existing pruritic skin diseases, $10.5 \%$ were diabetic and $7.9 \%$ were hypothyroid. History of usage of bath scrub was obtained from $76 \%$ patients and may be considered a major factor in the development of the condition.

Limitations of the Study- Level of significance was not calculated to confirm associations assessed in this study.

\section{CONCLUSION}

Histopathology is helpful to differentiate between macular and lichen amyloidosis. Cutaneous amyloidosis may often be associated with systemic disorders and hence must prompt one to investigate for them. Avoiding friction to the skin like use of bath-scrubs may help in preventing development of primary cutaneous amyloidosis.

\section{KEYWORDS}

Amyloidosis, PLCA, Friction, Bath Scrub.

HOW TO CITE THIS ARTICLE: George AE, Rajan RS, Nandakumar G. A clinical and histopathological study of cutaneous amyloidosis. J. Evolution Med. Dent. Sci. 2017;6(71):5050-5054, DOI: 10.14260/Jemds/2017/1098

\begin{abstract}
BACKGROUND
Amyloidosis is a disorder where a homogenous eosinophilic material derived from diverse proteins, is deposited in tissues. Amyloidosis can be broadly classified into systemic and localised (organ-specific).1,2 Cutaneous amyloidosis is a type of organ-specific amyloidosis and is further classified into primary localised cutaneous amyloidosis (PLCA) and secondary cutaneous amyloidosis. ${ }^{1,3}$ The major PLCA are papular (lichen), macular and nodular amyloidosis. Uncommon variants are dyschromic amyloidosis and familial amyloidosis. Dyskeratosis congenita, palmoplantar keratoderma, lupus erythematosus, dermatomyositis and atopic dermatitis have been associated with PLCA.
\end{abstract}

Financial or Other, Competing Interest: None.

Submission 31-07-2017, Peer Review 23-08-2017,

Acceptance 29-08-2017, Published 04-09-2017.

Corresponding Author:

Dr. Renjitha S. Rajan,

No. 25, Karthika, PTP Nagar,

Thiruvananthapuram-695038,

Kerala.

E-mail: bishfrvr@gmail.com

DOI: $10.14260 /$ jemds $/ 2017 / 1098$
Also, lupus erythematosus, hidradenitis suppurativa, cylindroma, pilomatricoma and basal cell carcinoma may show secondary amyloid deposits. ${ }^{4}$

PLCA is a benign but treatment-resistant condition and is very common in Asian countries. Usage of bath scrubs as well as chronic friction due to pre-existing itchy skin disorders are considered as causative factors. Friction leads to epidermal damage and keratinocyte apoptosis and it is thought that degenerating epidermal cells move into the dermis and is converted to amyloid. Immunohistochemical staining with anti-keratin antibody is positive in PLCA.

Histopathology shows homogenous, hyaline, eosinophilic material in haematoxylin and eosin stained sections. In macular and papular amyloidosis, the deposits are limited to papillary dermis and in nodular amyloid, deposits may involve entire thickness of dermis with occasional involvement of subcutaneous fat, blood vessels and sweat glands. The special stains for amyloid are triphenyl methane dyes, methyl and cresyl violet for demonstration of metachromasia, PAS, the substantive cotton dyes Congo red, Scarlet red, Dylon and Cardinal red. In Congo red stained sections, amyloid appears red or pink in colour and when viewed under polarised light microscope, apple green 
birefringence is seen. Ultrastructurally amyloid has a fibrillar appearance with rigid, non-branching and non-anastomosing fibrils of 8 to $12 \mathrm{~nm}$ width. ${ }^{1,5}$

\section{MATERIALS AND METHODS}

The study design was case series, including patients attending the Dermatology OPD of the hospital with clinical and histopathological evidence of cutaneous amyloidosis. There were a total of 38 patients. With an informed consent, a detailed history was taken with special reference to comorbidities and scrub usage. In patients with history of usage of bath scrubs, details like nature of scrub, duration of usage and the interval between usage and disease onset were noted.

A general examination, a detailed dermatological examination, routine blood and urine test, liver and renal function tests, random blood glucose test, urine Bence Jones proteins, serum electrophoresis, antinuclear antibody test and an ultrasound examination of abdomen were performed in all subjects.

Histopathological analysis of $10 \%$ formalin fixed skin samples with multiple haematoxylin and eosin stained sections and special stain (Congo red) were done. Only biopsy proven, Congo red positive cases were included in the study.

\section{RESULTS}

The study included 38 patients (13 males and 25 females), ranging from 20 to 70 years (mean $43.9 \pm 13.03$ ). Majority were females (66\%), most were unemployed (52.6\%) and all were right-handed individuals. Hyperpigmentation (42\%) and pruritus (32\%) were the major complaints. The duration of disease was very variable with $47.4 \%$ having it for $1-5$ years; $10.6 \%$ had it for more than 10 years.

Morphologically, 20 patients (53\%) were diagnosed as papular amyloidosis (Figure 1), $11(29 \%)$ as macular (Figure 2) and 7 (18\%) as biphasic. In general, lower limbs were predominantly affected in 16 (42.1\%); upper limbs in 9 $(23.68 \%)$; isolated posterior trunk involvement in 6 $(15.79 \%)$ and multiple sites were affected equally in 6 (15.79\%) patients. Left-sided involvement was seen in 19 (50\%) patients. (Table 1 ).

Among the 20 lichen amyloidosis patients, 10 had predominant left lower limb involvement, 4 had right lower limb involvement and 2 had isolated posterior trunk involvement. Among the 11 cases of macular amyloidosis, 8 had predominant upper limb involvement (left sided in 6) and posterior trunk alone affected in 3 cases of macular amyloidosis. Seven had biphasic amyloidosis with one each having head and neck lesions and posterior trunk involvement, 2 had left lower limb involvement, one had right upper limb involvement and multiple sites in 2 cases.

Among the 38 patients, 29 (76\%) gave history of bath scrub use. The scrub use was more prevalent among lichen amyloidosis patients (85\%), followed by biphasic amyloidosis (71.42\%) and macular amyloidosis (63.63\%). When considering all the scrub users together, 17 (58.6\%) of them had lichen amyloidosis, 7 (24.1\%) had macular and 5 (17.2\%) had biphasic amyloidosis.

Majority of them had used organic fibres of which coconut fibre was the most popular (68.9\%). Other fibres were "Khaskhas" grass (Vetiveria zizanioides), "Eencha" (Acacia caesia) and plastic. The duration of scrub usage and the interval between onset of scrub use and disease onset were highly varied. One patient had no correlation, having developed the disease prior to starting the scrub use while the remaining 28 gave history of having used scrub prior to onset of amyloidosis, among whom 8 (28.6\%) had used scrub for 6-10 years before they developed amyloidosis. An equal number of people ( 5 each, $17.9 \%$ ) had used scrubs for less than a year, 1-5 years and 16-20 years before the onset of the disease.

Thirty (78.9\%) patients had other diseases among whom, pre-existing itchy skin diseases like photodermatoses, chronic folliculitis, subacute eczema, lichen simplex chronicus, seborrhoeic dermatitis and recurrent pyoderma were present in $10(26.3 \%)$. Among the ten, 8 had lichen amyloidosis. Systemic conditions like hypercholesterolaemia was present in $7(18.4 \%)$ patients, hypertension in $5(13.2 \%)$, hypothyroidism in 3 (7.9\%), and chronic renal disease in one patient with lichen amyloidosis. History of diabetes mellitus was present in 4 patients $(10.5 \%)$ and one among these and an additional three were detected to have elevated random blood sugar on investigation.

Routine investigations on blood and urine and the liver and renal function tests were within normal limits and serum antinuclear antibody was negative for all patients. Ultrasound abdomen revealed hepatomegaly in 8 subjects, one of whom, a lady with history of carcinoma breast and mastectomy, showed coarsened echotexture of liver but was not willing for liver biopsy for confirmation of the possibility of either liver metastasis or amyloid deposits. Urine Bence Jones proteins was negative and serum electrophoresis pattern was normal in all subjects.

Histopathologically (Table 2), 32 patients (84.2\%) had features of lichen amyloidosis and $6(15.7 \%)$ had features of macular amyloidosis. All the 7 clinically suggestive biphasic amyloidosis and 6 macular amyloidosis turned out to be lichen amyloidosis, and one lichen amyloidosis was histologically macular amyloidosis. Significant hyperkeratosis, acanthosis, papillomatosis, focal and large globular amorphous material in the papillary dermis, scattered and periappendageal mononuclear cell infiltration in the dermis were seen in lichen amyloidosis (Figures 3) while basal layer pigmentation and dermal melanophages was seen in macular amyloidosis (Figures 4). The histological findings are shown in Table 3. If the histological diagnosis is taken into consideration, there was bath-scrub use in 25 (78.1\%) of the 32 lichen amyloidosis subjects and 4 (66.7\%) of the 6 macular amyloidosis subjects.

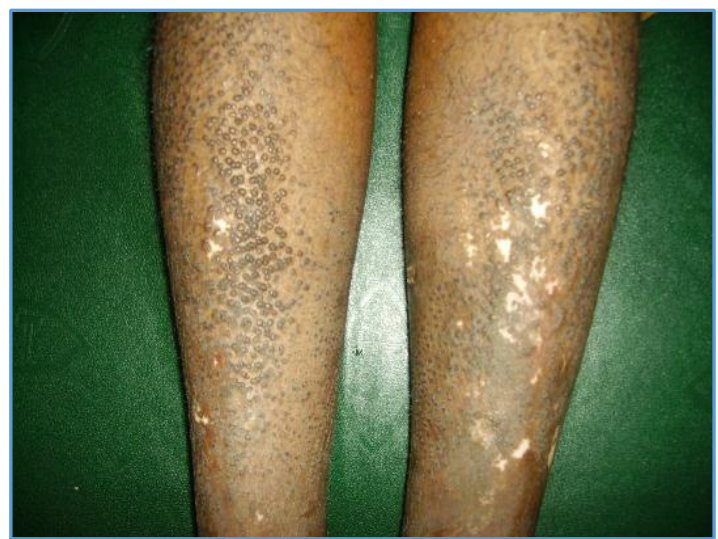

Figure 1. Lichen amyloidosis 


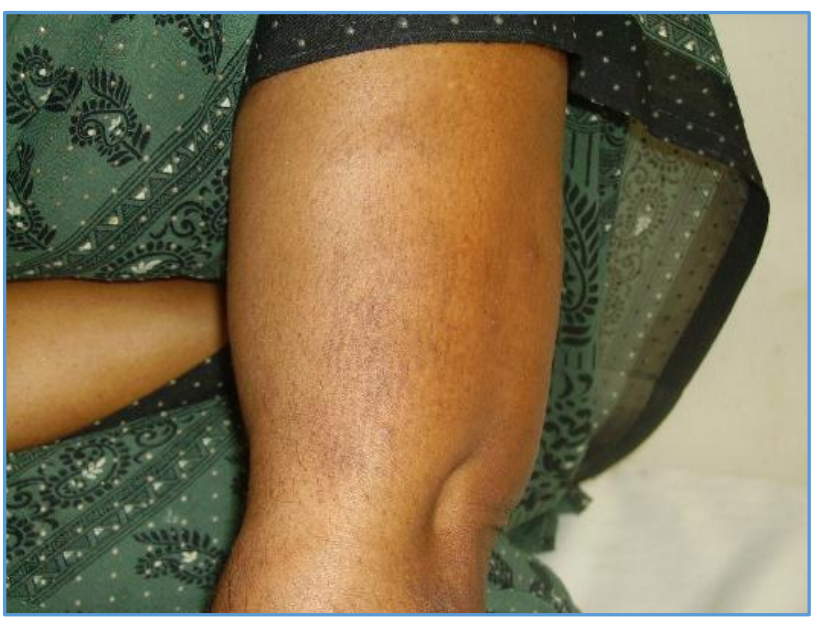

Figure 2. Macular Amyloidosis

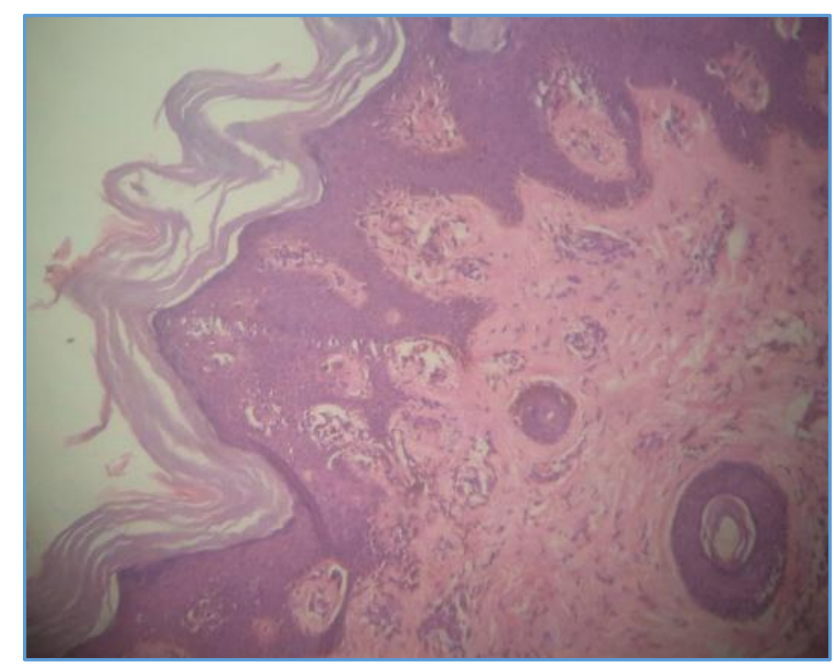

Figure 3. Haematoxylin and Eosin stained Section of Lichen amyloidosis at 40x Magnification showing Hyperkeratosis, Papillomatosis, Acanthosis and Dermal Infiltrate along with Amyloid

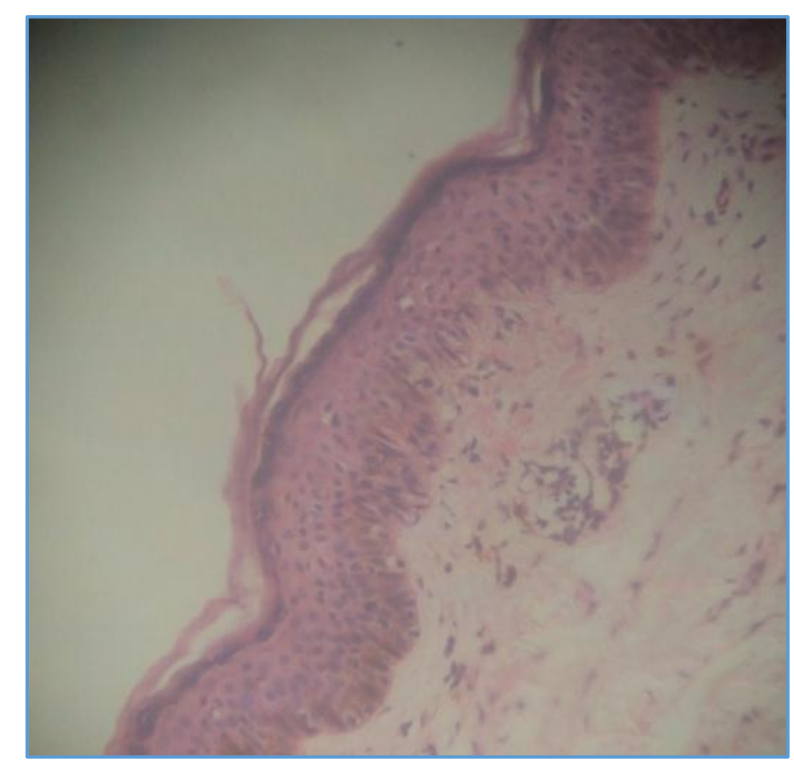

Figure 4. Haematoxylin and Eosin stained section at 100x Magnification of Macular Amyloidosis showing Mild Hyperkeratosis, Acanthosis, Increased Basal Layer Pigmentation and Focal Amyloid Deposit

\begin{tabular}{|c|c|c|}
\hline Sites & Frequency & Percent \\
\hline $\begin{array}{l}\text { Predominant right upper limb } \\
\text { involvement }\end{array}$ & 2 & 5.26 \\
\hline $\begin{array}{c}\text { Predominant right lower limb } \\
\text { involvement }\end{array}$ & 4 & 10.52 \\
\hline $\begin{array}{c}\text { Predominant left upper limb } \\
\text { involvement }\end{array}$ & 7 & 18.42 \\
\hline $\begin{array}{c}\text { Predominant left lower limb } \\
\text { involvement }\end{array}$ & 12 & 31.58 \\
\hline Anterior trunk involvement & 0 & 0 \\
\hline Isolated posterior trunk Involvement & 6 & 15.79 \\
\hline Head and neck involvement & 1 & 2.63 \\
\hline Multiple sites affected equally & 6 & 15.79 \\
\hline Total & 38 & 100 \\
\hline
\end{tabular}

\begin{tabular}{|c|c|}
\hline $\begin{array}{c}\text { Histopathological } \\
\text { Diagnosis }\end{array}$ & Clinical Diagnosis \\
\hline \multirow{2}{*}{ Lichen amyloidosis - 32} & Lichen amyloidosis - 19 \\
\cline { 2 - 2 } & Macular Amyloidosis - 6 \\
\cline { 2 - 2 } Miphasic Amyloidosis - 7 \\
\hline Macular Amyloidosis - 6 & Lichen amyloidosis - 1 \\
\cline { 2 - 2 } Table 2. Correlation between Histopathological and \\
\hline \multicolumn{2}{|c|}{ Clinical Diagnosis } \\
\hline
\end{tabular}

\begin{tabular}{|c|c|c|c|c|}
\hline $\begin{array}{c}\text { Histopathological } \\
\text { Findings }\end{array}$ & $\begin{array}{c}\text { Lichen } \\
\text { Amyloidosis }\end{array}$ & $\%$ & \begin{tabular}{c|} 
Macular \\
Amyloidosis
\end{tabular} & $\%$ \\
\hline Mild hyperkeratosis & 23 & 71.9 & 6 & 100 \\
\hline $\begin{array}{c}\text { Marked } \\
\text { hyperkeratosis }\end{array}$ & 9 & 28.1 & 0 & 0 \\
\hline Parakeratosis & 2 & 6.3 & 0 & 0 \\
\hline Keratotic plugging & 1 & 3.1 & 0 & 0 \\
\hline Acanthosis & 25 & 78.1 & 3 & 50 \\
\hline Papillomatosis & 19 & 59.4 & 0 & 0 \\
\hline $\begin{array}{c}\text { Increased basal layer } \\
\text { pigmentation }\end{array}$ & 1 & 3.1 & 2 & 33.3 \\
\hline Subepidermal cyst & 0 & 0 & 1 & 16.7 \\
\hline Subepidermal cleft & 1 & 3.1 & 0 & 0 \\
\hline $\begin{array}{c}\text { Focal amorphous } \\
\text { material in papillary } \\
\text { dermis }\end{array}$ & 32 & 100 & 6 & 100 \\
\hline $\begin{array}{c}\text { Large globular } \\
\text { amorphous material } \\
\text { in papillary dermis }\end{array}$ & 32 & 100 & 0 & 0 \\
\hline $\begin{array}{c}\text { Small focal } \\
\text { amorphous material } \\
\text { in papillary dermis }\end{array}$ & 0 & 0 & 6 & 100 \\
\hline $\begin{array}{c}\text { Melanophages in } \\
\text { the dermis }\end{array}$ & 12 & 37.5 & 4 & 66.7 \\
\hline $\begin{array}{c}\text { Scattered } \\
\text { mononuclear cell } \\
\text { infiltration in the } \\
\text { dermis } \\
\end{array}$ & 14 & 43.8 & 2 & 33.3 \\
\hline $\begin{array}{c}\text { Periappendageal } \\
\text { mononuclear cell } \\
\text { infiltration }\end{array}$ & 4 & 12.5 & 0 & 0 \\
\hline $\begin{array}{c}\text { Neutrophilic } \\
\text { infiltration in the } \\
\text { dermis } \\
\end{array}$ & 1 & 3.1 & 0 & 0 \\
\hline $\begin{array}{l}\text { Stellate fibroblasts } \\
\text { in the dermis }\end{array}$ & 1 & 3.1 & 0 & 0 \\
\hline \multicolumn{5}{|c|}{ Table 3. Histopathological Findings } \\
\hline
\end{tabular}




\section{DISCUSSION}

The study was done on 38 clinically and histopathologically proven cases of amyloidosis. The mean age was 43.9 years, majority were female and all were right handed.

Clinically, 53\% patients had papular amyloidosis, 29\% had macular and $18 \%$ had biphasic but none of the other variants of amyloidosis was noted in this study. Biphasic amyloidosis was noted more frequently than macular amyloidosis in the study of Vijaya B et al. ${ }^{6}$ Lower limbs $(42.1 \%)$ were more commonly affected than other areas, similar to observations in other studies. But when macular amyloidosis alone is considered, distribution was predominantly on upper limbs and posterior trunk similar to the findings of Mysore $\mathrm{V}$ et al and Somani $\mathrm{V}$ et al.7, 8 The left side especially the left limbs were more commonly involved.

The exact pathogenesis of PLCA is not clear, but prolonged friction, genetics and viral infection have all been proposed as factors inducing PLCA. The various dermatoses known to be associated with cutaneous amyloidosis were not seen in this study. Ten patients (26.3\%) had other itchy skin conditions like photodermatoses, chronic folliculitis, subacute eczema, etc., and eight of them had lichen amyloidosis.

PLCA has been known to accompany autoimmune connective tissue diseases and diabetes. Four (10.5\%) patients had diabetes mellitus in this study, of whom 2 had used scrub. Three diabetics had lichen amyloidosis and one had macular amyloidosis. In an Indian study of cutaneous manifestations of diabetes mellitus, $3 \%$ diabetics had macular amyloidosis. ${ }^{9}$ A study in Taiwan showed diabetes to be an important comorbidity among patients with PLCA. ${ }^{10}$ Hypothyroidism was seen in three (7.9\%) patients. Coexistence of macular amyloidosis and hypothyroidism in Indian women has been reported. ${ }^{11}$ Hypertension, hypercholesterolaemia and chronic renal disease was detected in this study but there are no reports of associations between PLCA and these diseases. Since chronic renal disease is often associated with pruritus and consequently friction, occurrence of lichen amyloidosis in that patient may not be incidental.

Most of the investigations done were normal for all subjects except elevated blood sugar values in four patients of whom only one was a known diabetic. Presence of cutaneous amyloidosis should prompt blood sugar assessment. Ultrasonography detected hepatomegaly in 8 patients but none had chronic liver disease.

This study shows that friction on the skin was very common among people with PLCA - 76\% had used scrubs while bathing. Also, the observation that the left side especially the left limbs were more involved and that all the patients here were right handed further supports the view that prolonged friction may be an aetiological factor for inducing amyloidosis. The condition was also more common among women who use bath scrubs more frequently among the study population. Among the 20 clinically lichen amyloidosis patients, $85 \%$ had used scrubs. A study conducted by Salim $\mathrm{T}$ et al showed that $56.7 \%$ of lichen amyloidosis patients had used scrubs. ${ }^{12}$ In this study, prevalence of scrub use was slightly less (63.63\%) among macular amyloidosis group. In a study in Oman, 90\% macular amyloidosis cases gave history of scrub use. ${ }^{7}$ Only $53.5 \%$ of macular amyloidosis cases had used scrubs in a study by
Somani VK et al. ${ }^{8}$ Among the 7 biphasic amyloidosis cases in this study, 5 had used scrubs.

An attempt was made to find out if there is any difference in the type of lesions in those who had used scrubs and those who had not. Among the 29 scrub users, clinically, 17 (58.6\%) developed lichen amyloidosis, 7 (24.1\%) developed macular amyloidosis and remaining 5 (17.2\%) biphasic amyloidosis whereas, among the 9 non-users, macular amyloidosis was seen most frequently (44.4\%); lichen amyloidosis in 33.3\% and biphasic amyloidosis, 22.2\%. Though statistical significance could not be reached due to small sample size, there was evident clinical preponderance of lichen amyloidosis among scrub users. Taking histological diagnosis into consideration, there was bath-scrub use in 25 of the 32 (78.1\%) lichen amyloidosis subjects and 4 of the $6(66.7 \%)$ macular amyloidosis subjects. But in literature, similar results were not obtained and both papular and macular amyloidosis are associated with scrub use.

Majority of patients in this study had used organic scrubs. In literature PLCA is associated with nylon scrub usage. Nylon scrubs were not used at all in this study probably because organic fibres like coconut fibres, "Ramacham" and "Eencha" are more acceptable and easily available in Kerala where this study was conducted. Mysore $\mathrm{V}$ et al in his study had also revealed other forms of friction to the skin by use of plant leaves and sticks for bathing and otherwise. ${ }^{7}$

In this study, histological distinction between macular and papular amyloidosis was based on the amount of amyloid deposited. When small focal deposits were seen in the papillary dermis, macular amyloidosis was diagnosed and wherever globular amyloid deposits were seen, which displaced the rete ridges, a diagnosis of lichen amyloidosis was made. Accordingly, histological diagnosis was lichen amyloidosis in 32 patients (84\%) and macular amyloidosis in 6 (16\%). There was disparity between clinical and histological diagnosis in 7 cases (Table 2). One patient with clinical lichen amyloidosis had histological features of macular amyloidosis. Six clinically macular amyloidosis and all 7 biphasic cases turned out to be lichen amyloidosis on histopathology.

Hyperkeratosis and acanthosis were more prominent in lichen amyloidosis compared to macular amyloidosis. All cases of lichen amyloidosis had hyperkeratosis identical to the findings of Salim T et al. ${ }^{12}$ Mild hyperkeratosis was seen in all macular amyloidosis patients. Acanthosis was seen in $78.1 \%$ cases of lichen amyloidosis and $50 \%$ cases on macular amyloidosis while in the study by Salim $\mathrm{T}$ et al, 90\% lichen amyloidosis patients had acanthosis. Papillomatosis was seen in $59.4 \%$ cases of lichen amyloidosis and in none of the macular amyloidosis cases whereas only $33.3 \%$ patients of Salim $\mathrm{T}$ et al had papillomatosis. ${ }^{12}$

Increased basal layer pigmentation was seen in 33.3\% macular amyloidosis cases but only in $3.1 \%$ lichen amyloidosis. Among the macular amyloidosis cases of Mysore $\mathrm{V}$ et al, basal layer pigmentation was seen in $80 \%$ subjects. $^{7}$ Melanophages in dermis was seen in $66.7 \%$ of macular amyloidosis versus only $37.5 \%$ of lichen amyloidosis. All macular amyloidosis subjects of Mysore $\mathrm{V}$ et al had pigment incontinence. ${ }^{7}$ Twenty subjects $(52.6 \%)$ in this study had mononuclear infiltrate in the dermis (of which 18 were lichen amyloidosis). In the study on lichen amyloidosis by Salim $\mathrm{T}$ et al, $70 \%$ cases had lymphocytic dermal infiltrate. ${ }^{12}$ Rare 
instances of subepidermal cleft formation reported in literature was seen in one case of lichen amyloidosis in this study also. ${ }^{13}$ One case of macular amyloidosis had subepidermal cyst formation.

From these observations, it may be added that besides the size of amyloid deposition, prominent hyperkeratosis, acanthosis and papillomatosis, other features like increased basal layer pigmentation and pigment incontinence (both more frequent in macular amyloidosis) as well as papillomatosis and periappendageal mononuclear and neutrophilic dermal infiltrate (more frequent in lichen amyloidosis) can be used for distinction between the two histologically.

\section{CONCLUSION}

The clinical and histopathological features seen in the cases of PLCA in this study were similar to those observed in other published studies although the basal layer pigmentary changes as well as dermal changes have not been reported commonly. Although the size of the amorphous amyloid deposits in the papillary dermis helped to differentiate between papular and macular amyloidosis, in cases where this is doubtful, basal layer pigmentation, pigment incontinence, papillomatosis and dermal infiltrate would aid in typing the disease.

Another important part of the study was to find out the associations of PLCA. Even though statistical significance could not be made, a large number of patients had preexisting pruritic skin disease and certain metabolic diseases, which are known to be associated with PLCA. Therefore, the presence of cutaneous amyloidosis should prompt one to investigate for associated conditions.

A major part of the study was devoted to analysing the role of friction in development of PLCA. Majority of patients had used scrubs while bathing, for prolonged periods and bath scrubs can be considered as an important risk factor in inducing amyloidosis and hence be better avoided.

\section{REFERENCES}

[1] Sarkany RPE, Breathnach SM, Morris AAM, et al. Metabolic and nutritional disorders. In: Burns $\mathrm{T}$, Breathnach S, Cox N, (eds). Rook's textbook of dermatology. $8^{\text {th }}$ edn. Vol: 3. West Sussex: Blackwell Publishing Ltd 2010:59.1-103.
[2] Seldin DC, Skinner M. Amyloidosis. In: Longo DL, Fauci AS, Kasper DL, et al. (eds). Harrison's principles of internal medicine. $18^{\text {th }}$ ed. Vol: 1 . New York: The McGraw Hill Companies Inc 2012:945-50.

[3] Lachmann HJ, Hawkins PN. Amyloidosis and the skin. In: Wolff K, Goldsmith LA, Katz SI, et al. (eds). Fitzpatrick's dermatology in general medicine. $7^{\text {th }}$ ed. Vol: 2. New York: The McGraw Hill Companies Inc 2008:1257-65.

[4] Franklin EC. Amyloid and amyloidosis of the skin. J Investig Dermatol 1976;67(3):451-6.

[5] Hashimoto K, Gross BG, Lever WF. Lichen amyloidosis. Histochemical and electron microscopic studies. J Investig Dermatol 1965;45(3):204-19.

[6] Vijaya B, Dalal BS, Manjunath GV. Primary cutaneous amyloidosis: a clinico-pathological study with emphasis on polarized microscopy. Indian J Pathol Microbiol 2012;55(2):170-4.

[7] Mysore V, Bhushnurmath SR, Muirhead DE, et al. Frictional amyloidosis in Oman - a study of ten cases. Indian J Dermatol Venereol Leprol 2002;68(1):28-32.

[8] Somani VK, Shailaja H, Sita VN, et al. Nylon friction dermatitis: a distinct subset of macular amyloidosis. Indian J Dermatol Venereol Leprol 1995;61(3):145-7.

[9] Bhat YJ, Gupta V, Kudyar RP. Cutaneous manifestations of diabetes mellitus. Int J Diab Dev Ctries 2006;26:152-5.

[10] Lee DD, Huang CK, Ko PC, et al. Association of primary cutaneous amyloidosis with atopic dermatitis: a nationwide population-based study in Taiwan. $\mathrm{Br}$ J Dermatol 2011;164(1):148-53.

[11] Chopra A, Pahuja K, Chopra D. Macular amyloidosis and hypothyroidism. Indian J Dermatol Venereol Leprol 1999;65(2):79-80.

[12] Salim T, Shenoi SD, Balachandran C, et al. Lichen amyloidosis: a study of clinical, histopathologic and immunofluorescence findings in 30 cases. Indian J Dermatol Venereol Leprol 2005;71(3):166-9.

[13] Maize JC, Maize JC, Metcalf J. Metabolic diseases of the skin. In: Elder DE, (edr). Lever's histopathology of the skin. $10^{\text {th }}$ edn. Philadelphia: Lippincott Williams \& Wilkins 2009:425-9. 